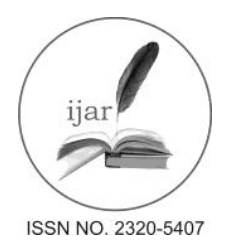

Journal homepage: http://www.journalijar.com

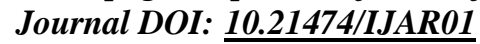

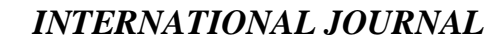

OF ADVANCED RESEARCH

RESEARCH ARTICLE

\title{
ASSESSMENT OF SOIL FERTILITY STATUS OF OILSEED RESEARCH PROGRAM, NAWALPUR,
} SARLAHI, NEPAL

\author{
Dinesh Khadka ${ }^{1}$, Sushil Lamichhane ${ }^{1}$, Razan Malla ${ }^{2}$ and Sushila Joshi ${ }^{1}$ \\ 1. Soil Science Division, NARC, Khumaltar, Lalitpur, Nepal \\ 2. Oilseed Research Program, NARC, Nawalpur, Sarlahi, Nepal
}

\section{Manuscript Info}

Manuscript History:

Received: 18 April 2016

Final Accepted: 22 May 2016

Published Online: June 2016

Key words:

Macronutrients;

Micronutrients; Oilseed

Crops; Research strategy; Soil

fertility maps

*Corresponding Author

Dinesh Khadka

\begin{abstract}
Soil fertility evaluation is most basic decision making tool for the sustainable soil nutrient management of a particular area. Thus, the present study was carried out to assess the soil fertility status of the Oilseed Research Program (ORP), Nawalpur, Sarlahi, Nepal. The study area is situated at the latitude $27^{\circ} 3{ }^{\prime} 35.8^{\prime}$ 'N and longitude $85^{\circ} 35^{\prime} 15.4^{\prime \prime} \mathrm{E}$ as well 130 masl altitude. A total of 38 soil samples were randomly collected based on the variability of land at a depth of $0-20 \mathrm{~cm}$. A GPS device was used to identify the location of the soil sampling points. Soil samples were analyzed for texture, $\mathrm{pH}, \mathrm{OM}, \mathrm{N}$, $\mathrm{P}_{2} \mathrm{O}_{5}, \mathrm{~K}_{2} \mathrm{O}, \mathrm{Ca}, \mathrm{Mg}, \mathrm{S}, \mathrm{B}, \mathrm{Fe}, \mathrm{Zn}, \mathrm{Cu}$ and $\mathrm{Mn}$ status following standard analytic methods in the laboratory of Soil Science Division, Khumaltar. The Arc-GIS 10.1 was used to prepare the soil fertility status maps. Assessment of soil test data showed that the structure was angular to sub-angular blocky and varied between brown- yellowish brown and dark grayish brown in colour. The sand, silt and clay content were $40.79 \pm 1.53 \%, 42.44 \pm 1.01 \%$ and $16.77 \pm 0.64 \%$, respectively and categorized as loam and sandy loam in texture. The soil was acidic in $\mathrm{pH}(5.03 \pm 0.04)$ and low in extractable calcium $(697.89 \pm 30 \mathrm{ppm})$, available sulphur $(2.15 \pm 0.19 \mathrm{ppm})$ and available zinc $(0.92 \pm 0.07 \mathrm{ppm})$. Whereas, organic matter $(2.02 \pm 0.11 \%)$, total nitrogen $(0.1 \pm 0.001 \%)$, extractable magnesium $(109.89 \pm 13.21 \mathrm{ppm})$ and available copper $(0.92 \pm 0.38 \mathrm{ppm})$ were medium in status. While, available phosphorus $(51.83 \pm 4.68 \mathrm{ppm})$, extractable potassium $(128.97 \pm 8.42 \mathrm{ppm})$, available boron $(1.24 \pm 0.09 \mathrm{ppm})$ and available manganese $(13.53 \pm 1.02 \mathrm{ppm})$ status were high. Similarly, available iron $(107.2 \pm 10.5 \mathrm{ppm})$ contains very high status. From this study, it can be concluded that for enhancing efficacy of the oilseed crops research, future research strategy should be built based on the soil fertility status of the research farm.
\end{abstract}

Copy Right IJAR, 2016.:All rights reserved.

\section{Introduction:-}

The evaluation of soil fertility is perhaps the most basic decision making tool for balanced and efficient nutrient management. It consists of estimating the available nutrient status of a soil for crop production. There are various techniques for soil fertility evaluation, among them soil testing is the most widely used research tool for making balanced and profit maximizing fertilizer recommendations, particularly for field crops. Soil testing can be defined as an acceptably accurate and rapid soil chemical analysis for assessing available nutrient status for making fertilizer recommendation(Roy et al., 2006). 
The texture, structure, colour etc. are important soil physical parameters. Similarly, soil reaction ( $\mathrm{pH}$ ), organic matter, macro and micronutrients etc. are also important soil chemical parameters. These properties play important role for the soil fertility and determined after soil testing (Brady and Nelson, 2004). Soil characterization in relation to evaluation of fertility status of the soils of an area or region is an important aspect in context of sustainable agriculture production. Describing the spatial variability of soil fertility across a field has been difficult until new technologies such as Global Positioning Systems (GPS) and Geographic Information Systems (GIS) were introduced. GIS is a powerful set of tools for collecting, storing, retrieving, transforming and displaying spatial data (Burrough and McDonnell, 1998).

Nepal Agricultural Research Council (NARC) was established to strengthen agriculture sector in the country through agriculture research. Oilseed Research Program, Nawalpur, Sarlahi, Nepal is an important wing among the research farms of NARC, in order to generate appropriate oilseed crop production technologies for the Nepal. Studies related to the soil fertility status of Oilseed Research Program, Nawalpur, Sarlahi, Nepal are scant. Therefore, it is important to investigate the soil fertility status and may provide valuable information relating oilseed crop research. Keeping these facts, the present study was conducted with the objective to assess the soil fertility status of Oilseed Research Program, Nawalpur, Sarlahi, Nepal.

\section{Materials and Methods:-}

\section{Study area:-}

The study was carried out at Oilseed Research Program, Nawalpur, Sarlahi, Nepal (Figure 1). The research farm is situated at a latitude $27^{\circ}{ }^{0} 3^{\prime} 35.8^{\prime}$ ' $\mathrm{N}$ and longitude $85^{\circ} 35^{\prime} 15.4^{\prime \prime} \mathrm{E}$ as well altitude $130 \mathrm{~m}$ above sea level.

\section{Soil sampling:-}

Surface soil samples (0-20 cm depth) were collected from Oilseed Research Program, Nawalpur, Sarlahi, Nepal during 2015. A total of 38 soil samples were collected from the research farm (Figure 2). The exact locations of the samples were recorded using a handheld GPS receiver. The random method based on the variability of the land was used for the soil samples collection.

\section{Laboratory analysis:-}

The collected soil samples were analyzed at laboratory of Soil Science Division, Khumaltar. The different soil parameters tested as well as methods adopted to analyze is shown on the Table 1.

Table 1:- Parameters and methods adopted for the laboratory analysis at Soil Science Division, Khumaltar

\begin{tabular}{|c|l|l|l|}
\hline S.N. & Parameters & Units & Methods \\
\hline 1 & Soil texture & & Hydrometer (Bouyoucos, 1927) \\
\hline 2. & Soil colour & & Munshell-colour chart \\
\hline 3. & Soil structure & & Field-feel \\
\hline 4. & Soil pH & $\%$ & Potentiometric 1:2 (Jackson, 1973) \\
\hline 5. & Soil organic matter & $\%$ & Walkely and Black (Walkely and Black, 1934) \\
\hline 6. & Total N & ppm & Kjeldahl (Bremner and Mulvaney, 1982) \\
\hline 7. & Available $\mathrm{P}_{2} \mathrm{O}_{5}$ & $\mathrm{ppm}$ & Olsen (Olsen et al., 1954) \\
\hline 8. & Extractable $\mathrm{K}_{2} \mathrm{O}$ & $\mathrm{ppm}$ & Emmonium acetate (Jackson, 1967) \\
\hline 9. & Extractable $\mathrm{Ca}$ & $\mathrm{ppm}$ & EDTA Titration (El Mahi, et.al., 1987) \\
\hline 10. & Extractable $\mathrm{Mg}$ & $\mathrm{ppm}$ & Turbidimetric (Verma, 1977) \\
\hline 11. & Available $\mathrm{S}$ & $\mathrm{ppm}$ & Hot water (Berger and Truog, 1939) \\
\hline 12. & Available $\mathrm{B}$ & $\mathrm{ppm}$ & DTPA (Lindsay and Norvell, 1978) \\
\hline 13. & Available Fe & $\mathrm{ppm}$ & DTPA (Lindsay and Norvell, 1978) \\
\hline 14. & Available $\mathrm{Zn}$ & $\mathrm{ppm}$ & DTPA (Lindsay and Norvell, 1978) \\
\hline 15. & Available $\mathrm{Mn}$ & $\mathrm{ppm}$ & DTPA (Lindsay and Norvell, 1978) \\
\hline 16. & Available $\mathrm{Cu}$ & & \\
\hline
\end{tabular}




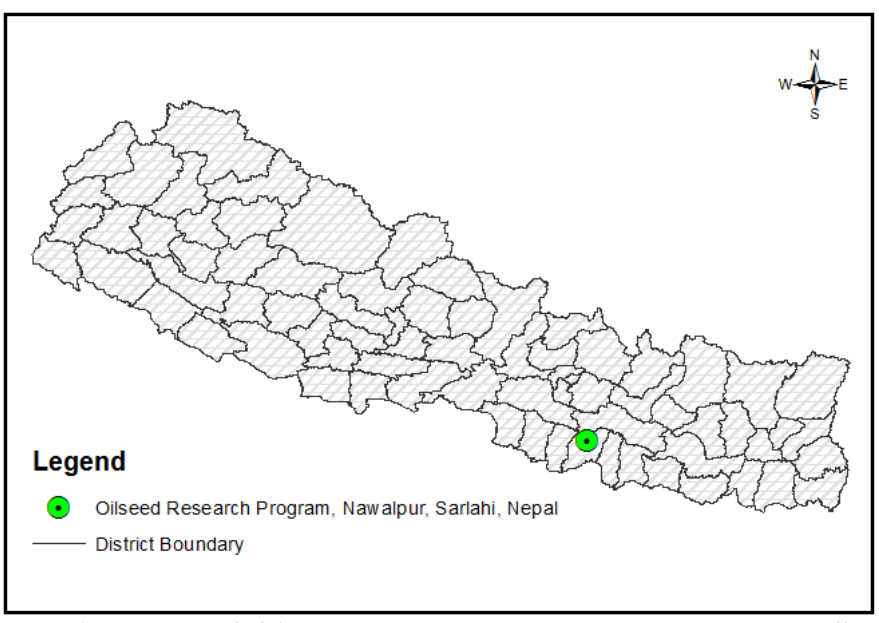

Figure 1:- Location Map of Oilseed Research Program, Nawalpur, Sarlahi, Nepal

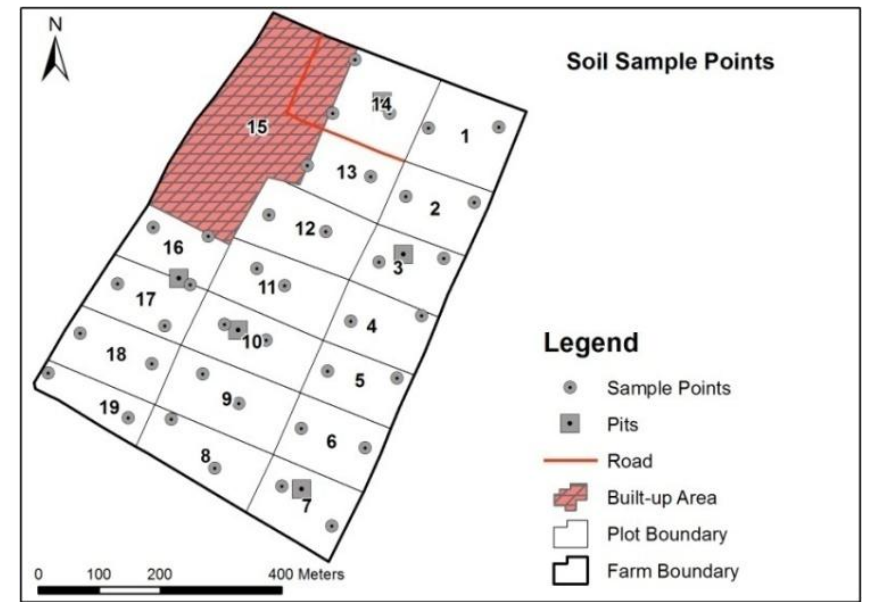

Figure 2:- Distribution of soil sample points during soil sampling

\section{Statistical analysis:-}

Descriptive statistics (mean, median, range, standard deviation, standard error, coefficient of variation) of soil parameters were computed using the Minitab 15 package. Rating (very low, low, medium, high and very high) of determined values were based on Soil Science Division, Khumaltar. The coefficient of variation was ranked according to the procedure of (Aweto, 1982) where, CV $<25 \%=$ low variation, $\mathrm{CV}>25<50 \%=$ moderate variation, $\mathrm{CV}>50 \%=$ high variation. Arc Map 10.1 with spatial analyst function of Arc GIS software was used to prepare soil fertility maps while interpolation method employed was ordinary kriging.

Similarly, the nutrient index was also determined by the formula given by Ramamoorthy and Bajaj (1969).

Nutrient Index (N.I.) $=\left(\mathbf{N}_{L} \times 1+\mathbf{N}_{M} \times 2+\mathbf{N}_{H} \times 3\right) / \mathbf{N}_{T}$

Where, $N_{L}, N_{M}$ and $N_{H}$ are number of samples falling in low, medium and high classes of nutrient status, respectively and $\mathrm{N}_{\mathrm{T}}$ is total number of samples analyzed for a given area. Similarly, interpretation was done as value given by Ramamoorthy shown on the Table 2 .

Table 2:- Rating chart of nutrient index

\begin{tabular}{|c|c|c|}
\hline S.N. & Nutrient Index & Value \\
\hline 1. & Low & $<1.67$ \\
\hline 2. & Medium & $1.67-2.33$ \\
\hline 3. & High & $>2.33$ \\
\hline
\end{tabular}




\section{Result and Discussion:-}

The soil fertility status of the study area was evaluated with respect to texture, colour, structure, $\mathrm{pH}$, organic matter, primary nutrients, secondary nutrients and micronutrients such as $\mathrm{B}, \mathrm{Fe}, \mathrm{Zn}, \mathrm{Cu}$, and $\mathrm{Mn}$ and the results obtained are presented and discussed in the following paragraphs.

\section{Soil texture:-}

Soil texture determines a number of physical and chemical properties of soils. It affects the infiltration and retention of water, soil aeration, absorption of nutrients, microbial activities, tillage and irrigation practices (Gupta, 2004). The results in Figure 3 shows that soil texture of the study area were predominantly loam type. The $\%$ sand were ranged from 24.2 to $61.6 \%$ with an average of $40.79 \%$ and that of $\%$ silt were 26.2 to $54.2 \%$ with an average of $42.44 \%$ while the range of $\%$ clay were 10.2 to $27.6 \%$ with an average of $16.77 \%$ (Table 3 ). The coefficients of variation between the soil samples were $23.1 \%, 14.7 \%$ and $23.46 \%$ for sand, silt and clay contents, respectively.

Table 3:- Soil Separates Status of Oilseed Research Program, Nawalpur, Sarlahi, Nepal

\begin{tabular}{|c|c|c|c|}
\hline \multirow{3}{*}{ Descriptive Statistics } & \multicolumn{3}{|c|}{ Soil Separates } \\
\hline & Sand & Silt & Clay \\
\hline & \multicolumn{3}{|c|}{$\%$} \\
\hline Mean & 40.79 & 42.44 & 16.77 \\
\hline Median & 38.2 & 43.5 & 17 \\
\hline StDev & 9.42 & 6.24 & 3.934 \\
\hline SE Mean & 1.53 & 1.01 & 0.638 \\
\hline Minimum & 24.2 & 26.2 & 10.2 \\
\hline Maximum & 61.6 & 54.2 & 27.6 \\
\hline $\mathrm{CV} \%$ & 23.1 & 14.7 & 23.46 \\
\hline
\end{tabular}

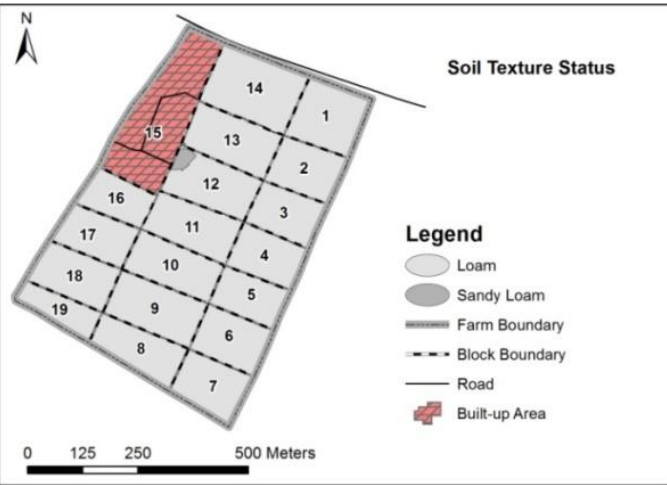

\section{Soil colour:-}

Figure 3:- Soil texture status of Oilseed Research Program, Nawalpur, Sarlahi, Nepal

Soil colour is an important soil parameter because it is an indirect measure of other important characteristics such as water drainage, aeration, and organic matter content (Foth, 1990). The different soil colour observed on the study area were 10YR 5/3 (brown), 10YR 4/3 (brown), 10YR 5/4 (yellowish brown) and 10YR 4/2 (dark grayish brown).

\section{Soil structure:-}

Soil structure refers to the pattern of spatial arrangement of soil particles in a soil mass (Brady and Weil, 2004). On the majority of the area, angular to sub angular blocky structured soil was observed.

\section{Soil reaction $(\mathbf{p H}):-$}

Soil reaction (usually expressed as $\mathrm{pH}$ value) is the degree of soil acidity or alkalinity, which is caused by particular chemical, mineralogical and/or biological environment. Soil reaction affects nutrient availability and toxicity, microbial activity, and root growth. The $\mathrm{pH}$ of soil was ranged from 4.42 to 5.67 with the mean value of 5.03 (Table 4). The results have shown that soil $\mathrm{pH}$ was very acidic (Figure 4). Soils having $\mathrm{pH}$ 6.0-7.5 is ideal for their proper growth and development oilseed crops. The very acidic $\mathrm{pH}$ reduces availability of most of the plant essential nutrients (Havlin et al., 2010). Therefore, periodically agricultural lime incorporation is imperative for amelioration of soil acidity. The soil reaction showed low variability $(5.12 \%)$ among the soil samples. 
Table 4. Soil fertility status of Oilseed Research Program, Nawalpur, Sarlahi, Nepal

\begin{tabular}{|c|c|c|c|c|c|}
\hline \multirow{3}{*}{ Descriptive Statistics } & \multicolumn{5}{|c|}{ Soil Fertility Parameters } \\
\hline & \multirow[t]{2}{*}{ pH } & $\mathbf{O M}$ & $\mathbf{N}$ & $\mathbf{P}_{2} \mathbf{O}_{5}$ & $\mathbf{K}_{2} \mathbf{O}$ \\
\hline & & \multicolumn{2}{|c|}{$\%$} & \multicolumn{2}{|c|}{ ppm } \\
\hline Mean & 5.03 & 2.02 & 0.10 & 51.83 & 128.97 \\
\hline Median & 5.04 & 1.98 & 0.10 & 49.07 & 114.60 \\
\hline StDev & 0.26 & 0.66 & 0.02 & 28.83 & 51.91 \\
\hline SE Mean & 0.04 & 0.11 & 0.001 & 4.68 & 8.42 \\
\hline Minimum & 4.42 & 0.24 & 0.05 & 5.86 & 69.60 \\
\hline Maximum & 5.67 & 3.26 & 0.13 & 113.28 & 255.60 \\
\hline $\mathrm{CV} \%$ & 5.12 & 32.49 & 19.51 & 55.62 & 40.25 \\
\hline
\end{tabular}

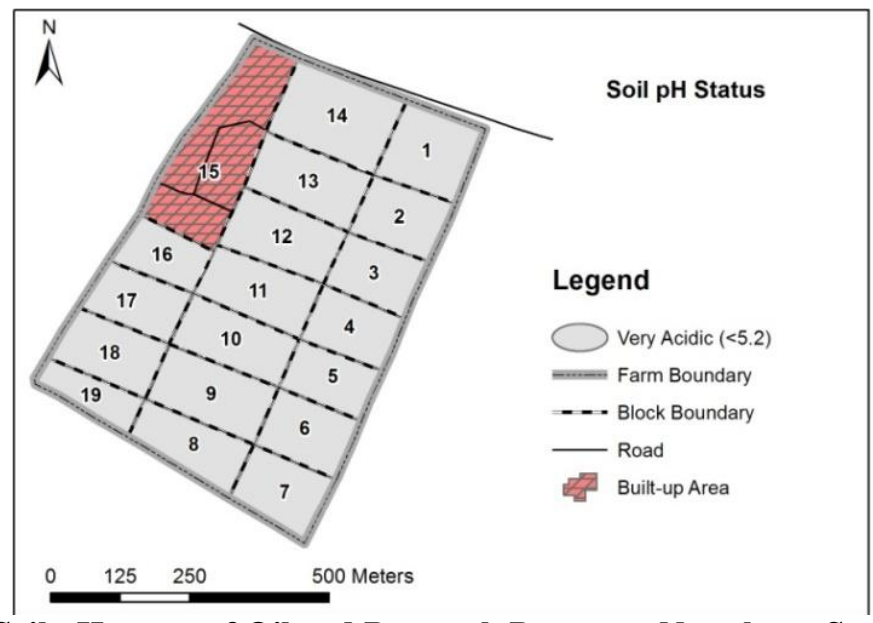

Figure 4:- Soil pH status of Oilseed Research Program, Nawalpur, Sarlahi, Nepal

Soil organic matter:-

Soil organic matter is important to make soil alive. It plays significant role for various functional activities in soils. The organic matter content was varied from 0.24 to $3.26 \%$ with an average value of $2.02 \%$ (Table 4 ). It indicates that the organic matter content was medium (Figure 5; Table 7). Organic matter showed moderate variability $(32.49 \%)$ in the investigated soil samples.

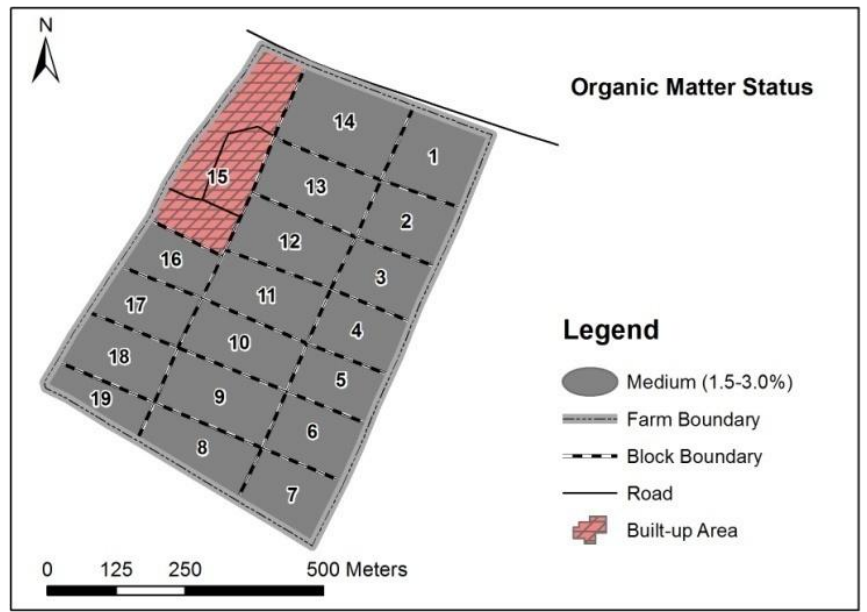

Figure 5:- Organic matter status of Oilseed Research Program, Nawalpur, Sarlahi, Nepal 


\section{Total nitrogen:-}

Nitrogen is the fourth most plant nutrient required highly by plants after carbon, oxygen and hydrogen, but it is one of the most deficient elements in the tropics for crop production (Mesfin, 1998). It is a substrate needed for the synthesis of amino acids and proteins which are constituents of protoplasm and chloroplast (Singh, 1996). The total nitrogen content was ranged from 0.05 to $0.13 \%$ with an average value of $0.10 \%$ (Table 4). This indicates medium status of total nitrogen (Figure 6; Table 7). Low variability (19.51\%) in total nitrogen was observed among the sampled soils.

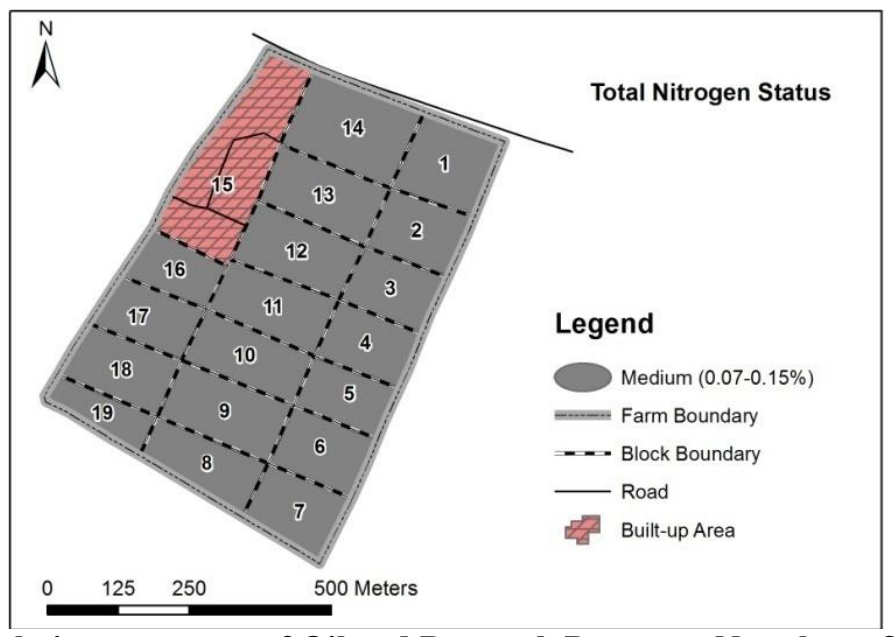

Figure 6:- Total nitrogen status of Oilseed Research Program, Nawalpur, Sarlahi, Nepal

\section{Available phosphorus:-}

Phosphorus is known as the master key to agriculture because lack of available $\mathrm{P}$ in the soils limits the growth of both cultivated and uncultivated plants (Foth and Ellis, 1997).The available phosphorus was ranged from 5.86 to $113.28 \mathrm{ppm}$ with the mean value of $51.83 \mathrm{ppm}$ (Table 4). This showed high status of available phosphorus (Figure 7; Table 7). The variation in the available phosphorus of the soil is high, with coefficients of variation of $55.62 \%$.

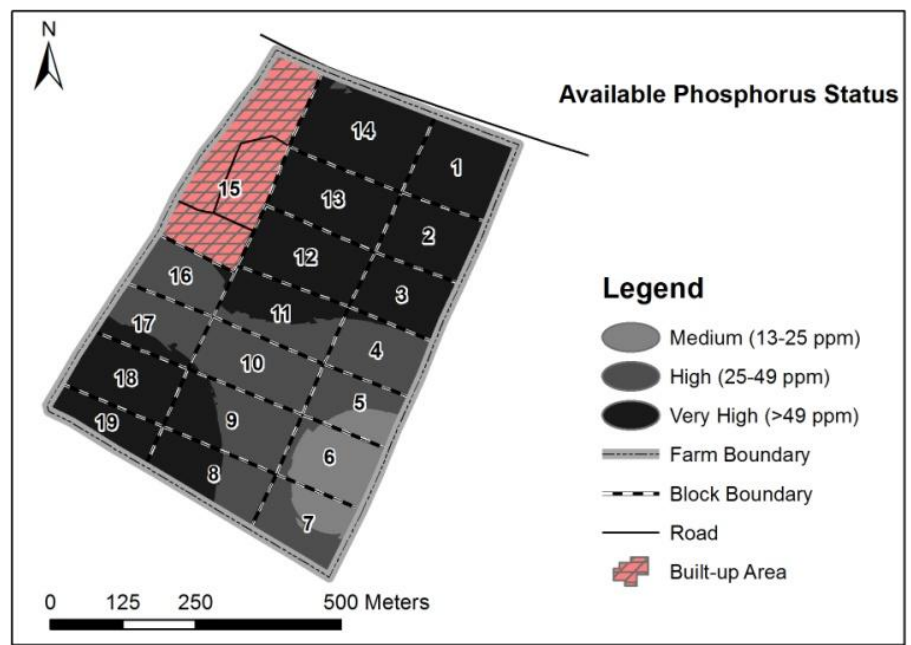

Figure 7:- Available phosphorus status of Oilseed Research Program, Nawalpur, Sarlahi, Nepal

\section{Extractable potassium}

Potassium is the third most important essential element next to $\mathrm{N}$ and $\mathrm{P}$ that limit plant productivity. It is one of the important elements for the development of the plant (Schoenholtz, 2000). The extractable potassium content was ranged from 69.6 to $255.6 \mathrm{ppm}$ with an average value of $128.97 \mathrm{ppm}$ (Table 4). This indicates high status of extractable potassium (Figure 8; Table 7). Moderate variability (40.25\%) in extractable potassium was observed among the soil samples. 


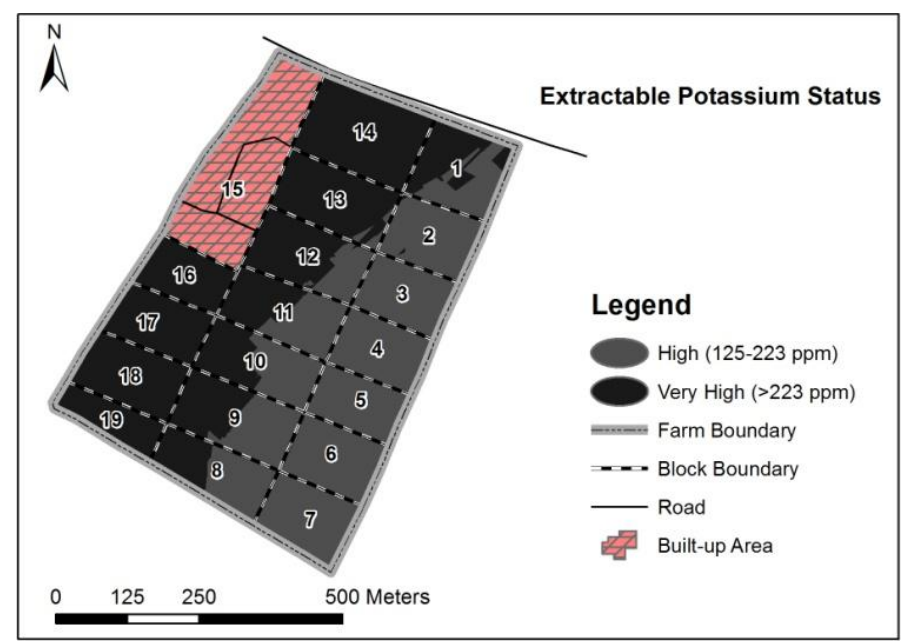

Figure 8:- Extractable potassium status of Oilseed Research Program, Nawalpur, Sarlahi, Nepal

Table 5:- Soil fertility status of Oilseed Research Program, Nawalpur, Sarlahi, Nepal

\begin{tabular}{|c|c|c|c|c|}
\hline \multirow{2}{*}{ Descriptive Statistics } & & \multicolumn{3}{|c|}{ Soil Fertility Parameters } \\
\cline { 2 - 5 } & Ca & Mg & S & B \\
\cline { 2 - 5 } & \multicolumn{3}{|c|}{$\mathbf{p p m}$} \\
\hline Mean & 697.89 & 109.89 & 2.15 & 1.24 \\
\hline Median & 710.00 & 90.00 & 2.26 & 1.20 \\
\hline StDev & 184.93 & 81.46 & 1.17 & 0.53 \\
\hline SE Mean & 30.00 & 13.21 & 0.19 & 0.09 \\
\hline Minimum & 180.00 & 12.00 & 0.05 & 0.26 \\
\hline Maximum & 1060.00 & 432.00 & 4.03 & 2.50 \\
\hline CV\% & 26.5 & 74.13 & 54.16 & 42.82 \\
\hline
\end{tabular}

\section{Extractable calcium:-}

Calcium plays a pre-dominant role in the composition of cell wall and protoplasm. It has been associated with carbohydrates and various organic acids (Mahajan and Billore, 2014). The extractable calcium content was ranged from 180 to $1060 \mathrm{ppm}$ with an average value of $697.89 \mathrm{ppm}$ (Table 5). In overall, low status of extractable calcium was observed (Figure 9; Table 7). Therefore, to make calcium adequate in the soils, soil reaction should be managed first as soon as possible. Moderate variability (26.5\%) in extractable calcium was observed among the soil samples.

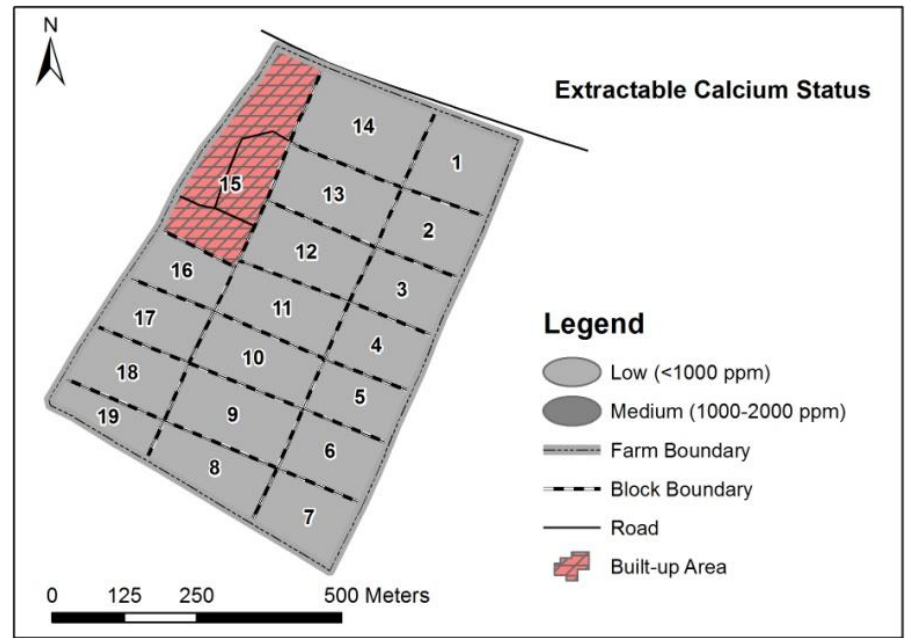

Figure 9:- Extractable calcium status of Oilseed Research Program, Nawalpur, Sarlahi, Nepal 


\section{Extractable magnesium:-}

Magnesium is a water soluble Cation and it is necessary for chlorophyll pigment in green plants (Mahajan and Billore, 2014). The extractable magnesium content was ranged from 12 to $432 \mathrm{ppm}$ with the mean value of 109.89 ppm (Table 5). This revealed medium content of extractable magnesium (Figure 10; Table 7). The variation in the extractable magnesium of the soil is high, with coefficients of variation of $74.13 \%$.

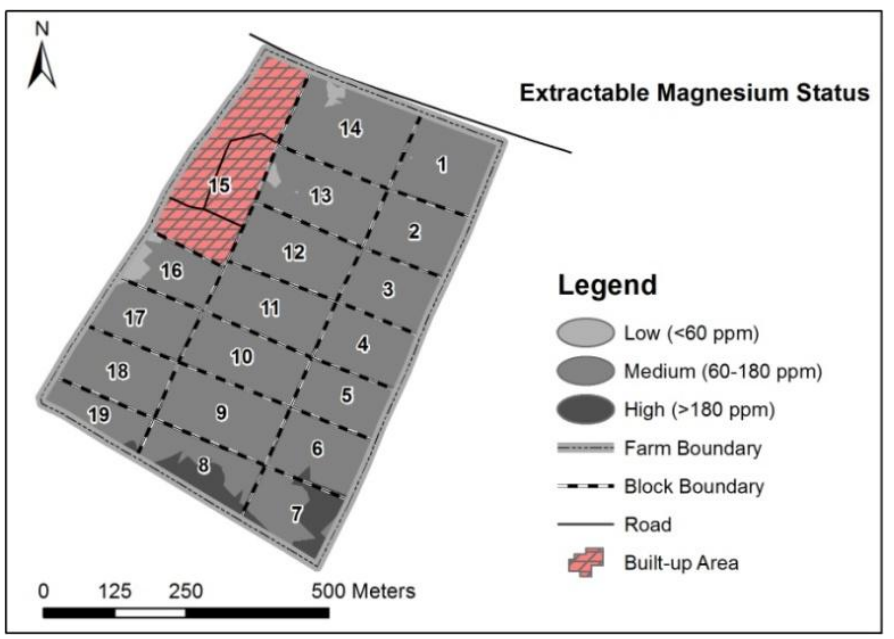

Figure 10:- Extractable magnesium status of Oilseed Research Program, Nawalpur, Sarlahi, Nepal

\section{Available sulphur:-}

Sulphur is an essential plant nutrient and plays a vital role in the synthesis of amino acids (methionine, cystein and cystine), proteins, chlorophyll and certain vitamins (Zhao et al., 1997; Havlin et al., 2010; Tiwari and Gupta, 2006). Sulphur is very important nutrient for oilseed crops. The available sulphur was varied from 0.05 to $4.03 \mathrm{ppm}$ with an average value of $2.15 \mathrm{ppm}$ (Table 5). In overall, available sulphur was low in status (Figure 11; Table 7). Therefore, regularly sulphur rich organic and inorganic source of materials should be incorporate. Available sulphur showed high variability $(54.16 \%)$ in the soil samples.

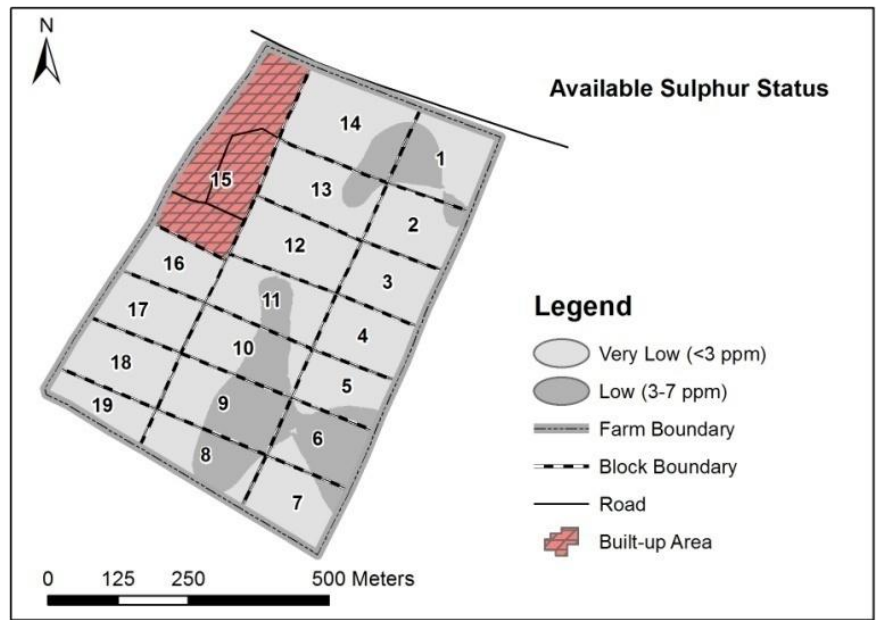

Figure 11:- Available sulphur status of Oilseed Research Program, Nawalpur, Sarlahi, Nepal

\section{Available boron:-}

Boron is one of two nonmetal micronutrients required by plants for their cell wall structural integrity (Havlin et al., 2010). The available boron content was ranged from 0.26 to $2.50 \mathrm{ppm}$ with a mean value of $1.24 \mathrm{ppm}$ (Table 5). This indicates medium content of available boron (Figure 12; Table 7). Moderate variability (42.82\%) in available boron was observed among the soil samples. 


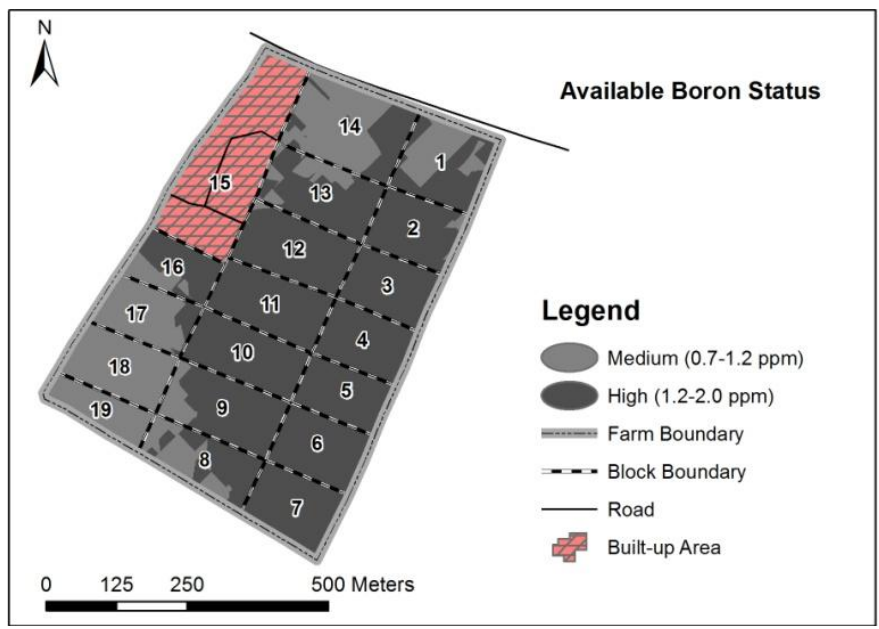

Figure 12:- Available boron status of Oilseed Research Program, Nawalpur, Sarlahi, Nepal

Table 6:- Soil Fertility Status of Oilseed Research Program, Nawalpur, Sarlahi, Nepal

\begin{tabular}{|c|c|c|c|c|}
\hline \multirow{3}{*}{ Descriptive Statistics } & \multicolumn{4}{|c|}{ Soil Fertility Parameters } \\
\hline & $\mathbf{F e}$ & $\mathbf{Z n}$ & $\mathbf{C u}$ & Mn \\
\hline & \multicolumn{4}{|c|}{ ppm } \\
\hline Mean & 107.2 & 0.92 & 0.92 & 13.53 \\
\hline Median & 96.5 & 0.97 & 0.9 & 12.05 \\
\hline StDev & 64.6 & 0.41 & 0.28 & 6.27 \\
\hline SE Mean & 10.5 & 0.07 & 0.05 & 1.02 \\
\hline Minimum & 4.4 & 0.22 & 0.38 & 5.18 \\
\hline Maximum & 262.9 & 1.7 & 1.5 & 30.22 \\
\hline CV\% & 60.22 & 44.43 & 30.31 & 46.32 \\
\hline
\end{tabular}

\section{Available iron:-}

Iron is the fourth most abundant element, comprising about 5\% of the earth's crust. In plants, it functions both as a structural component and as a co-factor for enzymatic reactions (Das, 2000). The available iron content was ranged from 4.4 to $262.9 \mathrm{ppm}$ with the mean value of $107.2 \mathrm{ppm}$ (Table 6). This indicates very high content of available iron (Figure 13; Table 7). Available iron showed high variability (60.22\%) among the soil samples.

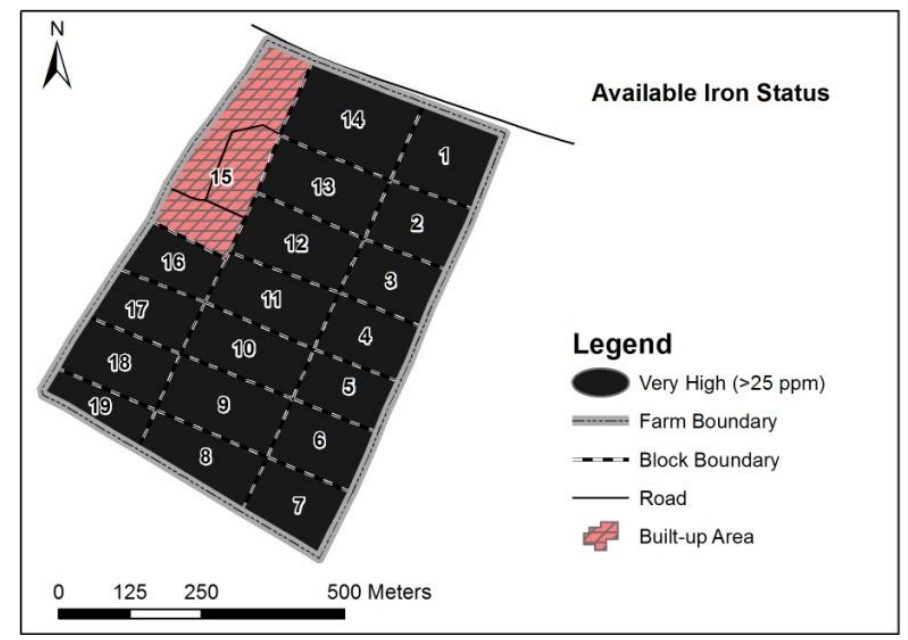

Figure 13:- Available iron status of Oilseed Research Program, Nawalpur, Sarlahi, Nepal 


\section{Available zinc:-}

Zinc is one of the eight trace elements which are essential for the normal healthy growth and reproduction of crop plants (Alloway, 2008). The available zinc was varied from 0.05 to $4.03 \mathrm{ppm}$ with an average value of $2.15 \mathrm{ppm}$ (Table 6). In overall, available zinc was medium in status (Figure 14; Table 7). The available zinc showed moderate variability (44.43\%) among the soil samples.

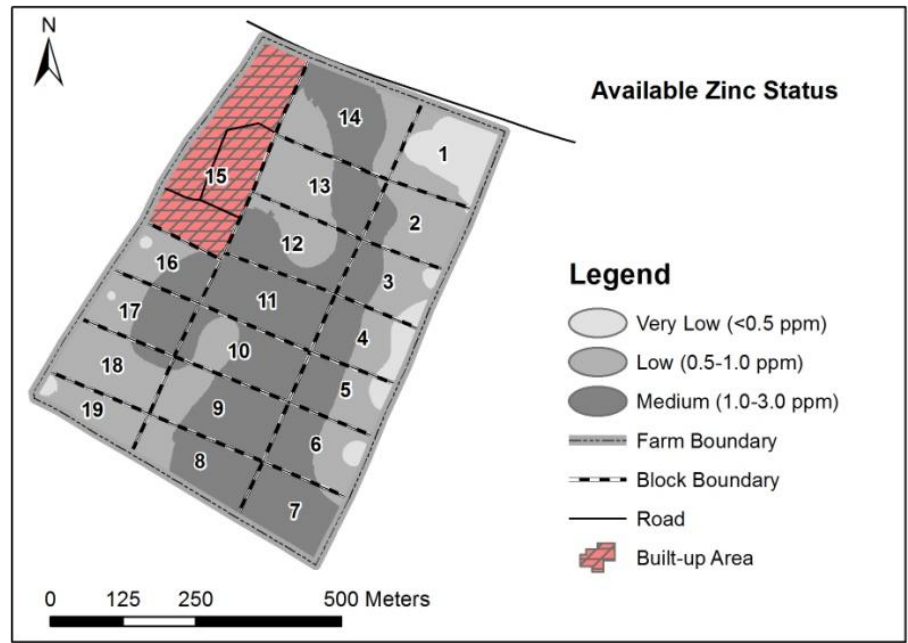

Figure 14:- Available zinc status of Oilseed Research Program, Nawalpur, Sarlahi, Nepal

\section{Available copper:-}

Copper is one of the oldest known metals. It is the $25^{\text {th }}$ most abundant element in the Earth's crust. The available copper content was ranged from 0.38 to $1.5 \mathrm{ppm}$ with the mean value of $0.92 \mathrm{ppm}$ (Table 6). This revealed medium status of available copper (Figure 15; Table 7). Moderate variability (30.31\%) in available copper was observed among the soil samples.

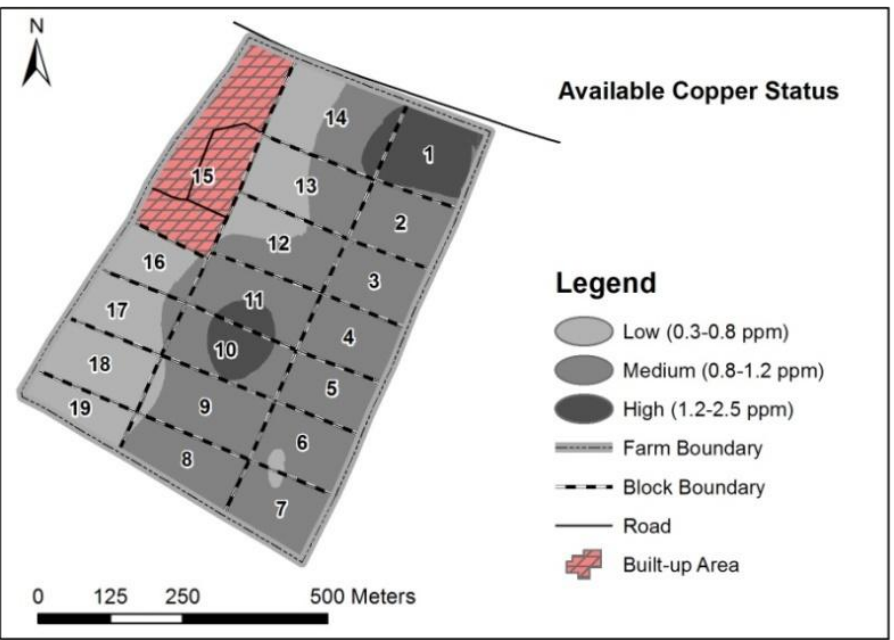

Figure 15:- Available copper status of Oilseed Research Program, Nawalpur, Sarlahi, Nepal

\section{Available manganese:-}

Manganese is the $10^{\text {th }}$ most abundant element on the surface of the earth. It is involved in many biochemical functions, primarily acting as an activator of enzymes such as dehydrogenases, transferases, hydroxylases, and decarboxylases (Graham, 1983; Burnell, 1988). The available manganese content was ranged from 5.18 to 30.22 ppm with an average value of $13.53 \mathrm{ppm}$ (Table 6). This indicates high content of available manganese (Figure 16; Table 7). The available manganese showed moderate variability (46.32\%) among the soil samples. 


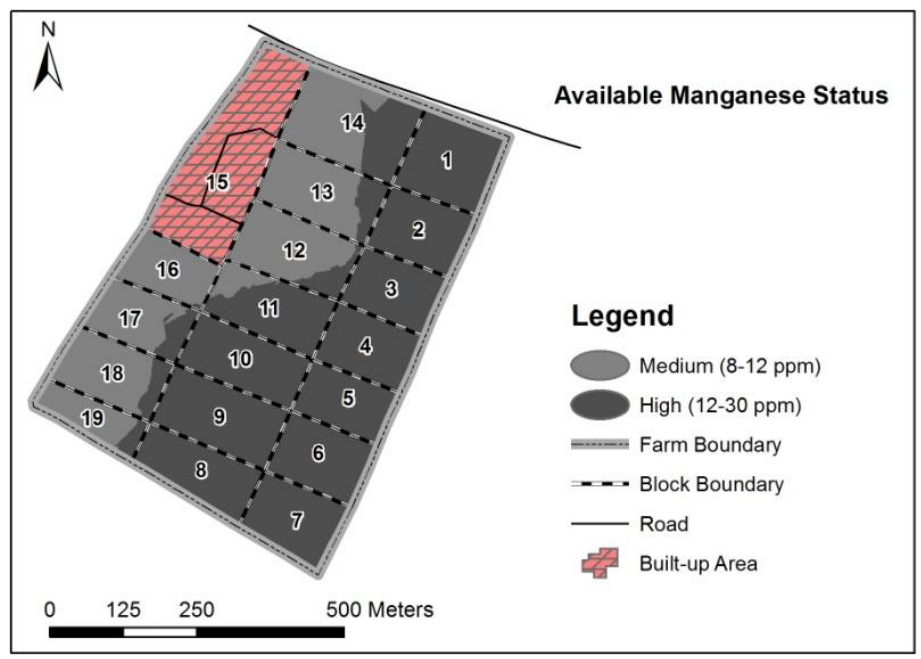

Figure 16:- Available manganese status of Oilseed Research Program, Nawalpur, Sarlahi, Nepal

Table 7:- Nutrient index of studied parameters of Oilseed Research Program, Nawalpur, Sarlahi, Nepal

\begin{tabular}{|c|c|c|c|c|c|c|}
\hline \multirow[b]{2}{*}{ S.N. } & \multirow[b]{2}{*}{ Parameters } & \multicolumn{3}{|c|}{ \% Samples category } & \multirow[b]{2}{*}{ Nutrient Index } & \multirow[b]{2}{*}{ Remarks } \\
\hline & & Low & Medium & High & & \\
\hline 1. & $\mathrm{OM}$ & 13.2 & 78.9 & 7.9 & 1.95 & Medium \\
\hline 2. & $\mathrm{~N}$ & 5.3 & 94.7 & - & 1.95 & Medium \\
\hline 3. & $\mathrm{P}_{2} \mathrm{O}_{5}$ & 2.6 & 18.4 & 78.9 & 2.76 & High \\
\hline 4. & $\mathrm{~K}_{2} \mathrm{O}$ & - & 73.7 & 26.3 & 2.26 & Medium \\
\hline 5. & $\mathrm{Ca}$ & 94.7 & 5.3 & - & 1.05 & Low \\
\hline 6. & $\mathrm{Mg}$ & 28.9 & 55.3 & 15.8 & 1.87 & Medium \\
\hline 7. & $\mathrm{~S}$ & 100 & - & - & 1.0 & Low \\
\hline 8. & $\mathrm{~B}$ & 10.5 & 39.5 & 50.0 & 2.39 & High \\
\hline 9. & $\mathrm{Fe}$ & 2.6 & 2.6 & 94.7 & 2.92 & High \\
\hline 10. & $\mathrm{Zn}$ & 52.6 & 47.4 & - & 1.47 & Low \\
\hline 11. & $\mathrm{Cu}$ & 34.2 & 52.6 & 13.2 & 1.79 & Medium \\
\hline 12. & $\mathrm{Mn}$ & 13.2 & 36.8 & 50.0 & 2.37 & High \\
\hline
\end{tabular}

\section{Conclusion:-}

In overall, the soil structure was angular to sub-angular blocky and varied between brown, yellowish brown and dark grayish brown in colour. The soil was very acidic in reaction and requires application of agricultural lime periodically. The calcium, sulphur and zinc status were low. The organic matter, nitrogen, magnesium and copper status were medium. The phosphorus, potassium, boron and manganese status were high. The iron status was very high. For enhancing research efficacy of the oilseed crops, future research strategy should be built based on the soil fertility status of the farm.

\section{Acknowledgement:-}

The authors would like to acknowledge Nepal Agricultural Research Council (NARC) for funding this research. We are very much thankful to Oilseed Research Program, Nawalpur, Sarlahi, Nepal for their cooperation. Similarly, support of the Soil Science Division, Khumaltar, Lalitpur, Nepal for providing laboratory facilities to analyze the soil samples as well as other technical support is highly acclaimed.

\section{References:-}

1. Alloway, B.J. (2008). Zinc in soils and crop nutrition. $2^{\text {nd }}$ Edition. International zinc association Brussels, Belgium, 139p.

2. Aweto, A.O. (1982). Variability of upper slope soils developed under sandstones in South-western Nigeria. Georg. J., 25:27-37.

3. Berger, K.C. and Truog, E. (1939). Boron determination in soils and plants. Ind. Eng. Anal. Ed., $11: 540$ - 545. 
4. Bouyoucos, G. J. (1962). Hydrometer method improved for making particle-size analysis of soils. Agron. J., 53: 464- 465.

5. Brady, N.C. and Weil, R.R. (2002). The nature and properties of soils. $13^{\text {th }}$ Edition. Pearson Education, New Jersey.

6. Bremner, J.M. and Mulvaney, C.S. (1982). Nitrogen total. In: Page, A.L. (ed) Methods of soil analysis. Agron. No. 9, Part 2: Chemical and microbiological properties. $2^{\text {nd }}$ edition. Am. Soc. Agron., Madison, WI, USA. Pp. 595- 624.

7. Burnell, J.N. (1988). The biochemistry of manganese in plants. In: Graham RD, Hannam RJ, Uren NC (eds) Manganese in Soils and Plants, Kluwer Academic Publishers, Dordrecht, The Netherland. Pp. 125-137.

8. Burrough, P.A. and McDonnell, R.A. (1998). Principle of geographic information systems. Oxford: Oxford University Press.

9. Das, K.D. (2000). Micronutrients: their behavior in soils and plants. Kalyani Publishers, New Delhi. Pp.113121.

10. El Mahi,Y., Ibrahim, I.S., AbdelMajid, H.M. and Eltilib, A.M. (1987). A simple method for determination of calcium and magnesium carbonate in soils. Soil Sci. Soc.Am.J., 51:1152-1155.

11. Foth, H.D. (1990). Fundamentals of soil science. John Wiley \& Sons, New York.

12. Foth, H.D. and Ellis, B.G. (1997). Soil fertility. $2^{\text {nd }}$ Edition. Lewis CRC Press LLC., USA. 290pp.

13. Goovaerts, P. (1998). Geo-statistical tools for characterizing the spatial variability of microbiological and physicochemical soil properties. Biol. Fertil. Soil, 27:315-344.

14. Graham, R.D. (1983). Effect of nutrient stress on susceptibility of plants to disease with particular reference to the trace elements. Adv. Bot. Res., 10:221-276.

15. Gupta, P.K. (2004). Soil, plant, water and fertilizer analysis. Shyam Printing Press, Agrobios, India. 38pp.

16. Havlin, H.L., Beaton, J.D., Tisdale, S.L. and Nelson, W.L. (2010). Soil Fertility and Fertilizers- an introduction to nutrient management. $7^{\text {th }}$ Edition. PHI Learning Private Limited, New Delhi.

17. Jackson, M.L. (1973). Soil chemical analysis. Prentice Hall of India Pvt. Ltd., New Delhi.

18. Lindsay, W.L. and Norvell, WA. (1978). Development of a DTPA soil test for zinc, iron, manganese, and copper. Soil Sci. Soc. Am. J., 42: $421-428$.

19. Mahajan, S. and Billore, D. (2014). Assessment of physicochemical characteristics of the soil of Nagchoon pond Khandwa, MP, India. Research Journal of Chemical Sciences, 4(1):26-30.

20. Mengel, K. and Kirby, E.A. (1987). Principles of Plant Nutrition. Panima Publishing Corpration, New Delhi, India.

21. Mesfin, A. (1998). Nature and management of Ethiopian soils. Alemaya University of Agriculture, Ethiopia. $272 \mathrm{pp}$.

22. Nael, M., Khademi, H. and Hajabbasi, M. (2004). Response of soil quality indicators and their spatial variability to land degradation in central Iran. Applied Soil Ecology, 27: 221-232.

23. Olsen, S.R., Cole, C.V., Watanabe, F.S. and Dean, L.A. (1954). Estimation of available phosphorus in soils by extraction with sodium bicarbonate. U. S. Dep. Agric. Circ. 9, USA. 39pp.

24. Ramamurthy, B. and Bajaj, J.C. (1969). Available nitrogen, phosphorus and potassium status of Indian soils. Fert. News, 14:25-36.

25. Roy, R.N., Finck, A., Blair, G.J. and Tandon, H.L.S. (2006). Plant nutrition for food security. Food and Agriculture Organization of the United Nations.

26. Schoenholtz, S.H. (2000). A review of chemical and physical properties as indicators of forest soil quality: challenges and opportunities. Forest Ecology and Management, 138:335-356.

27. Singh, S.S. (1996). Soil Fertility and Nutrient Management. Kalyani Publisher, New Delhi, India.

28. Tiwari, K.N. and Gupta, B.R. (2006). Sulphur for sustainable high yield agriculture in Uttar Pradesh. Indian Journal of Fertilizers, 1: 37-52.

29. Verma, B.C. (1977). An improved turbidimetric procedure for the determination of sulphate in plants and soils. Talanta, 24: $49-50$.

30. Walkley, A.J. and Black, I.A. (1934). Estimation of soil organic carbon by the chromic acid titration method. Soil Sci., 37: 29-38.

31. Zhao, F.J., Whiters, P.J.A., Evans, E.J., Monaghan, J., Salomon, S.E., Shewry, P.R. and McGrath, S.P. (1997). Sulphur nutrition: an important factor for the quality of wheat and rapeseed. Soil Science and Plant Nutrition, 43: $1137-1140$. 